\title{
Flow structure along the cross-section of an open-channel caused by patch of submerged vegetation
}

\author{
Bitki parçasının açık kanal enkesiti boyunca neden olduğu akım yapısı
}

\author{
Ayșe YÜKSEL OZAN ${ }^{*}$ \\ ${ }^{1}$ Civil Engineering Department, Engineering Faculty, Adnan Menderes University, Aydın, Turkey. \\ ayseyukselozan@gmail.com
}

Received/Geliș Tarihi: 26.02.2016, Accepted/Kabul Tarihi: 23.05.2016

* Corresponding author/Yazışılan Yazar

doi: $10.5505 /$ pajes.2016.71300

Research Article/Araștırma Makalesi

\begin{abstract}
Vegetation is crucial part of ecosystem in natural rivers. The flow structure changed mostly in streamwise, lateral, and vertical directions because of the Kelvin-Helmholtz instability caused by vegetated canopy. In this study, the flow characteristics under the effect of limited-length submerged vegetation patch were investigated experimentally. The rigid submerged vegetation layer with $1.2 \mathrm{~m}$ length, $0.6 \mathrm{~m}$ width were used to simulate limited-length submerged vegetation patch in the experiments. The vegetation layer was composed using rigid circular plastic dowels with $0.01 \mathrm{~m}$ diameter and $0.05 \mathrm{~m}$ height. Two different vegetation densities which are $N_{1}=161 \mathrm{IP} / \mathrm{m}^{2}$ and $N_{2}=1149 \mathrm{IP} / \mathrm{m}^{2}$ were used to obtain the effect of vegetation density. The velocity measurements were performed using ADV. According to the results obtained, the presence of vegetation causes strong gradient in the flow structure over the cross-section of the channel. Higher vegetation intensity causes higher velocity gradient in the velocity distribution. Additionally, "S-curve" shaped depth averaged stream-wise velocity profile was obtained along the cross-section with steeper curve for higher vegetation intensity. Turbulent kinetic energy was obtained higher in the vegetated part comparing to non-vegetated part. Furthermore, turbulent kinetic energy peak occurs at the vegetation interface between inner and outer layer in the vegetated part for higher vegetation intensity. Beside this, strong momentum exchange appears at the interface between the inner layer and outer layer at the vegetated part for higher vegetation intensity. The discharge capacity of the channel was also examined and found that discharge capacity decreases with increasing vegetation density.
\end{abstract}

Keywords: Vegetation patch, Open channel flow, Turbulence, Velocity profile

\begin{abstract}
Öz
Akarsulardaki bitki yapısı ekosistemin önemli bir parçasıldr. Akım yapısl, bitki tabakası nedeniyle meydana gelen Kelvin-Helmholtz istikrarsızlığından dolayı akım doğrultusunda, yanal ve düşey doğrultularda ciddi miktarda değişmektedir. Bu çalışmada, sınırlı uzunlukta batık bitki parçasının etkisindeki akım yapısı deneysel olarak araştırılmıştır. Deneylerde sınırlı uzunlukta batık bitki parçası, $1.2 \mathrm{~m}$ uzunluğunda ve $0.6 \mathrm{~m}$ genişliğinde rijit batık bitki tabakası kullanılarak benzeştirilmiştir. Bitki tabakası, $0.01 \mathrm{~m}$ çapında ve $0.05 \mathrm{~m}$ yüksekliğinde dairesel kesitli rijit plastik boru parçaları kullanılarak benzeștirilmiştir. Bitki yoğunluğunun etkisini belirlemek için, $N_{1}=161 \mathrm{IP} / \mathrm{m}^{2}$ and $N_{2}=1149 \mathrm{IP} / \mathrm{m}^{2}$ olmak üzere iki farkl yoğunlukta bitki tabakası kullanılmıștır. Hız ölçümleri ADV kullanılarak yapılmıştır. Elde edilen sonuçlara göre, bitki tabakası kanal enkesiti boyunca akım yapısında ciddi bir değișime neden olmaktadır. Büyük yoğunluğa sahip bitki tabakası, hız dağılımında daha yüksek oranda hız değișimine sebep olmuștur. Buna ilaveten, kanal enkesiti boyunca derinlik ortalama hız dağılımında, büyük yoğunlukta daha dik olmak kaydıyla, bir S-eğrisi belirlenmiștir. Türbülans kinetik enerji, bitki tabakasının olduğu bölgede bitki tabakası olmayan bölgeye nazaran daha fazla meydana gelmiştir. Ayrıca en yüksek türbülans kinetik enerji değeri, yüksek yoğunlukta bitki tabakasının bulunduğu kısımda, bitki ile akım arasındaki sınır bölgede meydana gelmiștir. Bunun yanı sıra büyük yoğunlukta, bitki tabakasının bulunduğu kısımda, bitki ile akım arasındaki sınır bölgede kuvvetli momentum değișimi belirlenmiștir. Ayrıca, kanalın debi kapasitesi incelenmiş ve bitki yoğunluğundaki artışın debi kapasitesini azalttığı görülmüștür.
\end{abstract}

Anahtar kelimeler: Bitki parçası, Açık kanal akımı, Türbülans, Hız dağılımı

\section{Introduction}

The flow area is quite influenced by submerged and/or emergent vegetation in the natural rivers [1]. Aquatic plants affect the flow characteristics such as the velocity distributions, turbulence and coherent structure, as well as mass and momentum exchanges between the vegetated and non-vegetated zones [2]. The velocity distribution in water column is proportional to the bed shear stress for nonvegetated flow [3]-[5]. However, in vegetated flow, it is mostly affected by the vegetation drag because of the vegetation roughness which is dominant than river bed roughness [3]-[5]. There is an intricate interplay between vegetation and flow that causes vortices and swirling motions of various length scales [6]. Moreover, there are strong velocity gradients and important secondary currents in the flow through partially and/or submerged vegetated channels [1]. These flow phenomenon causes shear layer formation between the vegetated layer and overlying water [1]. The vegetation effect on the flow phenomenon has become very important on river and coastal restoration, the establishment of flood control and coastal preservation projects [1].

A great number of studies have been presented in the past decades to examine the flow structure affected by aquatic canopy in river flows. In these studies mainly three type vegetation considered which are submerged and fully vegetated bed [2],[6]-[12], submerged and partially vegetated bed along the channel [13] and emerged and partially vegetated bed along the channel [12],[14],[15].

Huai et al. performed a study about submerged vegetation effect on the velocity distribution in open-channel flow [8]. They considered rigid submerged vegetation which covers all channel bed in their experiments and model. They recommended a three-layer model to represent velocity distribution in vertical direction. Nehal and Yan investigate the 
flow resistance and velocity distribution caused by the instream-emergent vegetation [16]. They used artificialflexible vegetation in the experiments. They obtained that density of vegetation has big effect on the resistance and that the Manning coefficient is a function of the flow depth.

Nezu and Onitsuka performed a study on turbulence caused by vegetated zone in an open-channel. They established the vegetated zone at a half channel through the channel [13]. They obtained that the secondary current intensity and the turbulent energy rise is directly proportional to increasing Froude number. Moreover, they also define that higher Froude number and higher vegetation intensity causes higher horizontal vortices near the free surface. Chen studied on a representative roughness height for the surface layer, and developed an approach for bulk flow velocity and resistance coefficient [10]. Cheng stated that roughness length scale should be considered for evaluation of submerged vegetation resistance in open channel flows and proposed a representative roughness height which defines the flow resistance caused by submerged vegetation in the surface layer [9].

Nepf and Vivoni performed an experimental study on flow caused by depth-limited vegetation layer which means the transition from the emergent canopy to the terrestrial (submerged) canopy [12]. They offer that vegetated flow area can be considered in two parts which are upper canopy and lower canopy. They called the upper canopy as 'vertical exchange zone'. In vertical exchange zone, turbulence exchange between overlying water and vegetated layer is dynamically important to the turbulence and momentum balance. They stated that there is an important shear layer which causes significant turbulence between vegetated layer and overlying water. They also defined lower canopy which is 'longitudinal exchange zone'. There is interaction between the layer and surrounding water mostly through longitudinal advection in longitudinal exchange zone. In the upper canopy, vegetation elements creates turbulence locally and the total momentum is a balance of drag caused by vegetation and pressure gradient [12]. Moreover, there is just longitudinal exchange zone in emergent canopies where a vertical exchange zone presents at the top of the canopy and deepens into the canopy as the depth of submergence increases in submerged canopies [12]. Apart from this, Li et al.) suggested that this type two-layer model which is broadly used is not sufficient to reflect the distinctive features of canopy turbulence [17]. For this purpose, they propose a two-layer dynamic model of vegetated flows, consisting of a basal layer and a suspension layer. They offer effective relative roughness height to reflect the friction factor of the suspension layer. They also proposed an empirical formula for the relationship between the effective relative roughness height and friction factor for the suspension layer is then developed, providing a basis for estimating the bulk flow velocity, Manning coefficient and Chezy coefficient.

Okamoto et al. studied on the flow structure at the wake region behind the finite-length vegetation patch [18]. They considered emergent rigid vegetation elements for finitelength vegetation patch. They obtain that when vegetation patch length rises there is rapid turbulent improvement at the wake region. Moreover, vegetation patch affects the wake region importantly and increasing vegetation patch length causes longer wake region length [18].
A great number of experimental studies about the flow structure under the effect of vegetation have concentrated fully-vegetated bed mostly. However, aquatic vegetation presents in patches with limited length in many natural rivers. Nevertheless, how to describe vegetation-affected velocity profiles caused by submerged partially vegetation patch with limited length remain challenging. This study focused on to investigate how the flow features (velocity, turbulence) affected by submerged rigid vegetation patch with limited length for different porosities over the cross-section in an open-channel.

\section{Experimental procedure}

Measurements were performed in an $11 \mathrm{~m}$ long, $1.2 \mathrm{~m}$ wide and $0.75 \mathrm{~cm}$ height flume with glass walls and a concrete base in the Civil Engineering Laboratory at Adnan Menderes University (Figure 1). The flume has an interior re-circulating system providing a steady flow. Figure 1 shows the experimental set-up where vegetated part is $B_{v}=0.6 \mathrm{~m}$, non-vegetated part is $B_{n v}=0.6 \mathrm{~m}$, total width is $B=1.2 \mathrm{~m}$, vegetation height is $h_{v}=0.05 \mathrm{~m}$, the length of vegetated area $L_{v}=1.2 \mathrm{~m}$, and water depth is $H=0.25 \mathrm{~m}$. Relative water depth which is $h_{v} / H=0.2 \mathrm{~m}$, and relative vegetation patch width which is $B_{v} / B=0.2 \mathrm{~m}$ were kept constant. A finite-length submerged vegetation patch constructed by placing $10 \mathrm{~mm}$ diameter rigid circular plastic dowels in a plywood sheet. The rigid cylinders were placed in a staggered, equilateral array (Figure 2 and Figure 3). The densities of vegetation were chosen as $N_{0}=0 \mathrm{IP} / \mathrm{m}^{2}, N_{1}=$ $161 \mathrm{IP} / \mathrm{m}^{2}$, and $N_{2}=1149 \mathrm{IP} / \mathrm{m}^{2}$ in the experiments. Here, $\mathrm{IP} / \mathrm{m}^{2}$ means individual plant number per square meter. Bricks were installed along the cross section of the flume at the entrance and outlet of the flume to provide smooth inlet and outlet conditions. A pointer gauge was used to measure the flow depths and the turbulence velocity measurements were conducted by SONTEK Acoustic Doppler Velocimeter (ADV). Total discharge $\left(Q=u_{d m} A=0.033 \mathrm{~m}^{3} / \mathrm{s}\right)$, Reynolds Number $\left(R e=u_{d m} H / v=28000\right)$, and Froude Number $\left(F r=u_{d m} / \sqrt{g H}=0.07\right)$ were calculated using mean depth averaged velocity $\left(u_{d m}\right)$ for non-vegetated case. Here, $H$ is flow depth, $v$ is kinematic viscosity and $g$ is the gravitational acceleration. Depth averaged velocity $\left(u_{d}\right)$ was calculated by integrating velocity along the vertical direction $(z / H \leq 0.58)$ for every water column considered. Afterwards, mean depth averaged velocity $\left(u_{d m}\right)$ was calculated by taking average of all water columns' depth averaged velocity values $\left(u_{d}\right)$. Mean depth averaged velocity $\left(u_{d m}\right)$ for non-vegetated case was used for non-dimensionalization of the figures in Section 3.

The measurement cross-section was set at $0.75 L_{v}$ which corresponds to $5 \mathrm{~m}$ from bricks at the inlet of the flume (Figure $1 \mathrm{~b}$ ). Ten vertical measurement lines, which are $0.15 \mathrm{~m}$, $0.25 \mathrm{~m}, 0.35 \mathrm{~m}, 0.45 \mathrm{~m}, 0.55 \mathrm{~m}, 0.65 \mathrm{~m}, 0.75 \mathrm{~m}, 0.85 \mathrm{~m}, 0.95 \mathrm{~m}$, and $0.105 \mathrm{~m}$ illustrated by Y15, Y25, Y35, Y45, Y55, Y65, Y75, Y85, Y95, and Y105 respectively in Figure 1a where the relative lateral location $y / B$ is in the range of $0.125,0.21,0.29$, $0.375,0.46,0.54,0.625,0.71,0.79$ and 0.875 respectively were chosen for the cross-section measurements. Vertical measurement intervals between two vertical points vary between $0.01 \mathrm{~m}$ and $0.025 \mathrm{~m}$ at different flow depths. The velocity measurements were performed during $120 \mathrm{~s}$ with 3000 sampling number at $25 \mathrm{~Hz}$ with ADV. 

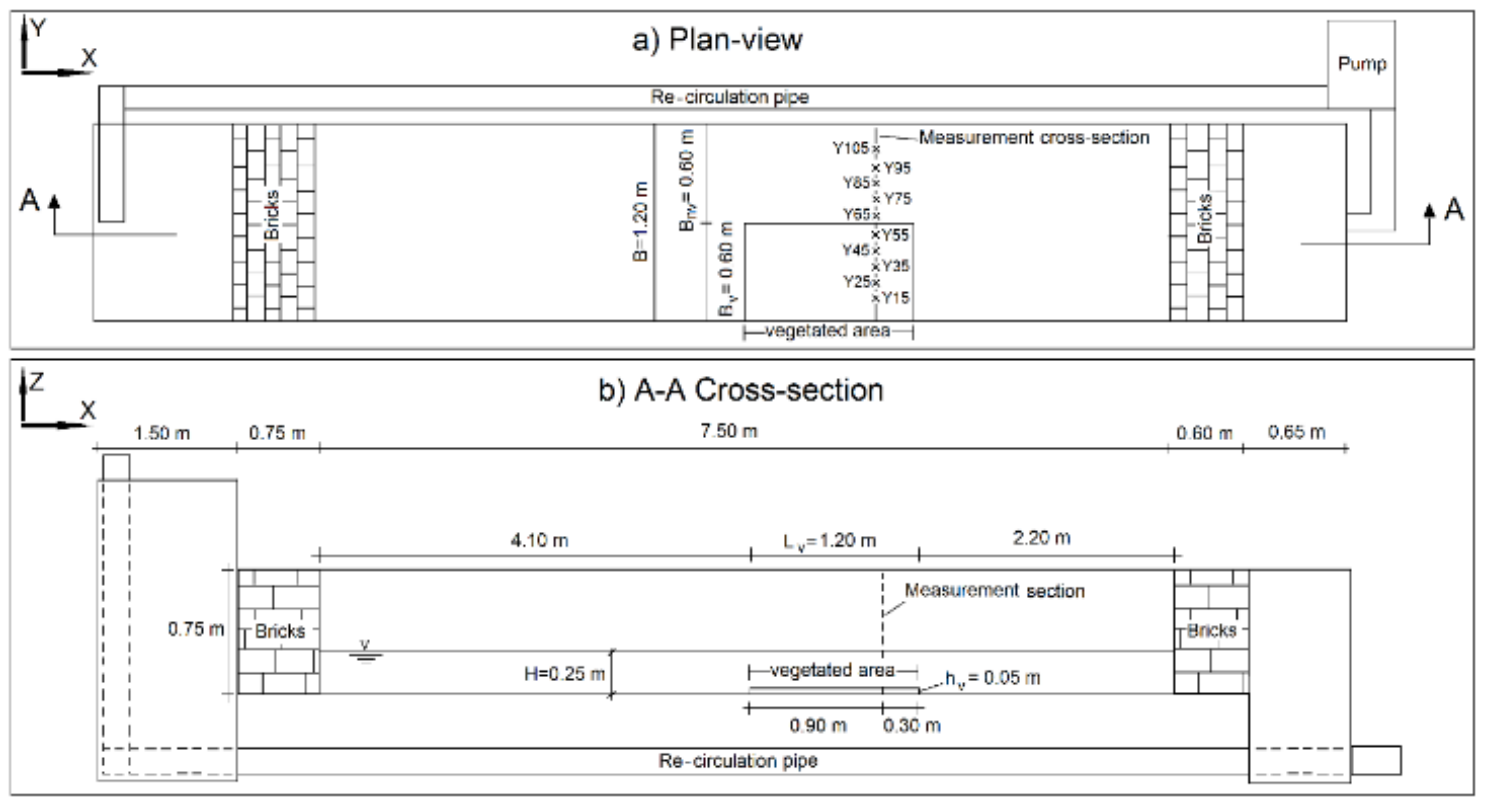

Figure 1: (a): Plan-view of the flume, (b): A-A cross-section of the flume.
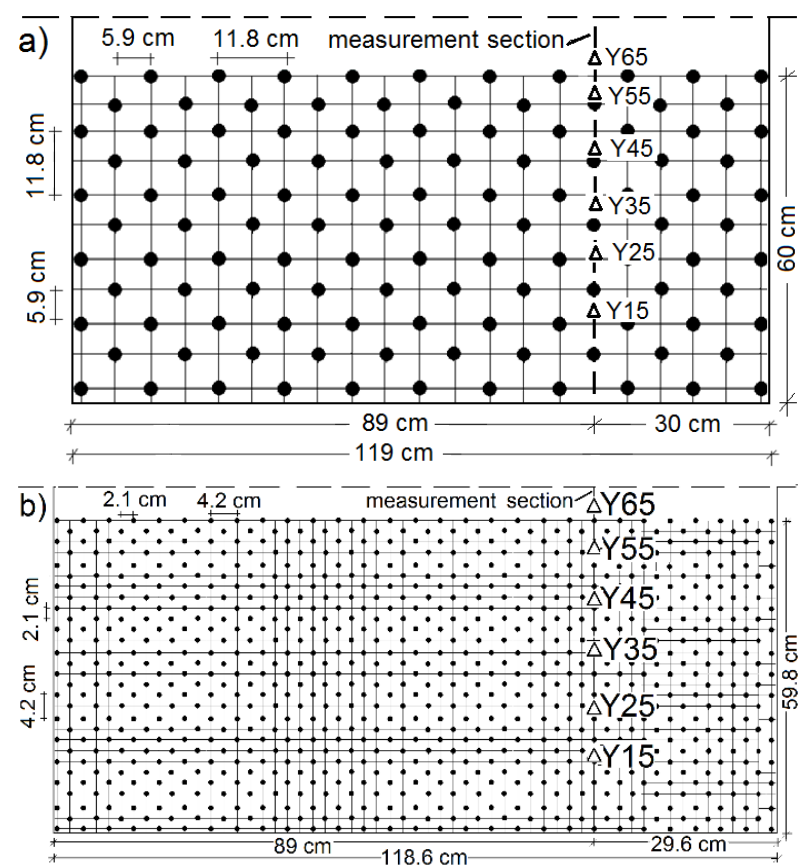

Figure 2: Measurement cross-section along the vegetation layer, a): $N_{1}=161 \mathrm{IP} / \mathrm{m}^{2}$, b): $N_{2}=1149 \mathrm{IP} / \mathrm{m}^{2}$.

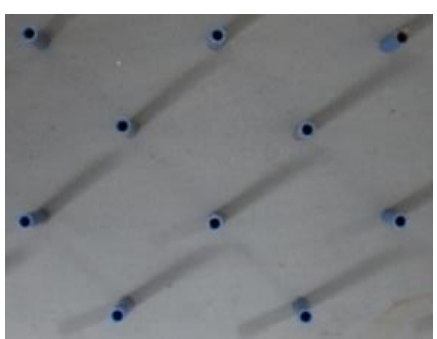

(a)

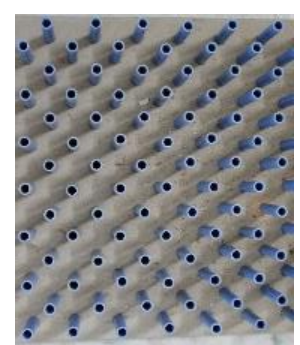

(b)

\section{Experimental results and discussion}

Figure 4 and 5 represent the normalized streamwise velocity $\left(u / u_{d m}\right)$ distribution along the vertical lines at different lateral distances over the measurement cross-section. In the results, inner layer is defined as vegetated layer where $z / H \leq$ 0.20 in the vertical direction and outer layer is defined between $0.20<z / H<1.0$ in the vertical direction.

The dotted line shows the vegetation height $\left(h_{v}\right)$. The logarithmic line were plotted for non-vegetated case in the figures. The logarithmic lines were obtained by using the law for rough boundaries which is

$$
\frac{u}{u_{*}}=\frac{1}{\kappa} \ln \left(\frac{30 z}{k_{s}}\right)
$$

Where $u$ is streamwise point velocity, $u_{*}$ is local shear velocity, $\kappa$ is von Karman's constant, $z$ is distance from the measurement point to the bed, $k_{s}$ is the Nikuradse equivalent bed roughness. Nikuradse equivalent bed roughness was taken as $k_{s}=0.18 \times 10^{-3} \mathrm{~m}$ which is for well planned wood since plywood was used as bed material in the experiments. It is seen that the vertical distribution of streamwise velocity for the non-vegetated case fits the logarithmic relationship very well in the channel.

In the vegetated part (Figure 4), the streamwise velocity decreases along the vertical direction because of the drag force applied by vegetation. In the vegetated part negative values were measured since the measurement point was placed at the wake region. In the vegetated part, the streamwise velocity decreases for both porosities at inner and outer region of the vegetation. Furthermore, decreasing in the velocity is considerably high with higher vegetation intensity $\left(N_{2}=1149 \mathrm{IP} / \mathrm{m}^{2}\right)$ in both region. In the non-vegetated part (Figure 5), the streamwise velocity is higher for vegetated cases than $\mathrm{NV}$ case $\left(N_{0}=0 \mathrm{IP} / \mathrm{m}^{2}\right)$ in the inner region.

Figure 3: Vegetation layers. (a): $N_{1}=161 \mathrm{IP} / \mathrm{m}^{2}$, (b): $N_{2}=1149 \mathrm{IP} / \mathrm{m}^{2}$. 


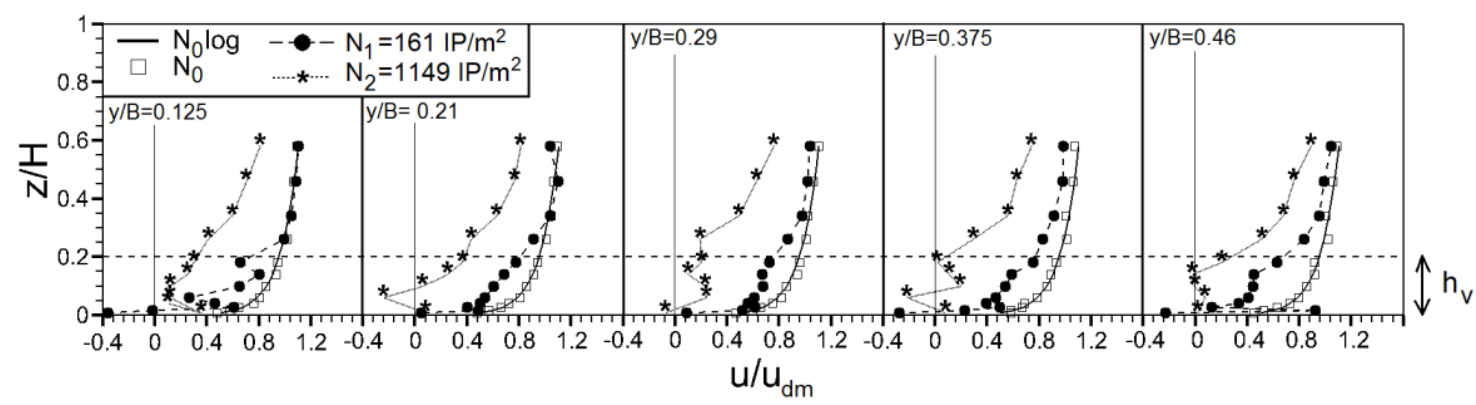

Figure 4: Normalized mean-streamwise velocity $\left(u / u_{d m}\right)$ distribution along the vertical lines at vegetated part.

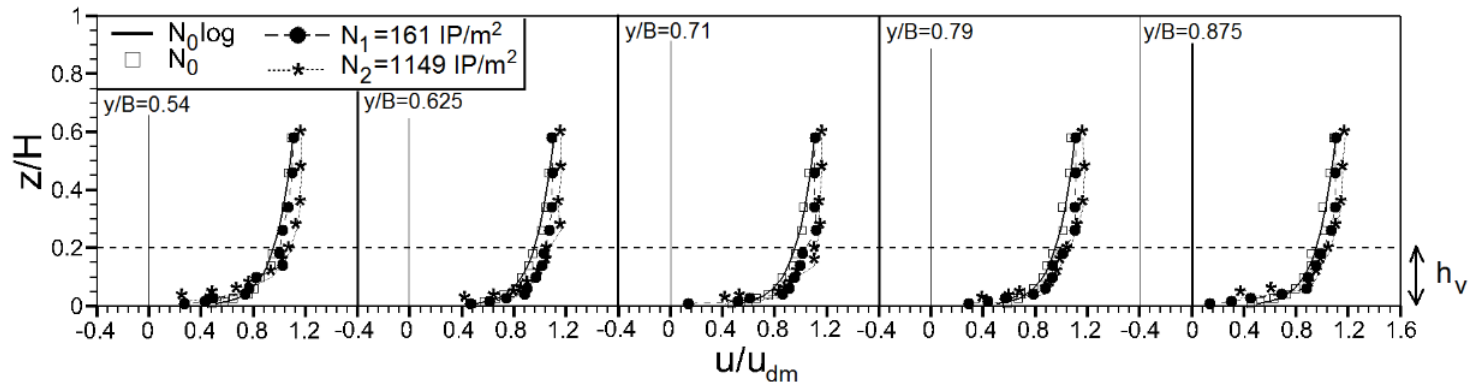

Figure 5: Normalized mean-streamwise velocity $\left(u / u_{d m}\right)$ distribution along the vertical lines at non-vegetated part.

The depth-averaged streamwise velocity distribution is given in Figure 6 for all cases. The vegetation patch greatly reduces the streamwise velocity in the vegetated part and increases the streamwise velocity in the non-vegetated part (Figure 6). This creates a strong velocity gradient over the channel crosssection. This is most pronounced in the case of higher vegetation density $\left(N_{2}=1149 \mathrm{IP} / \mathrm{m}^{2}\right)$. The stream wise velocity is $60 \%$ higher in non-vegetated part than vegetated part for $N_{2}=1149 \mathrm{IP} / \mathrm{m}^{2}$ when it is $15 \%$ for $N_{1}=161 \mathrm{IP} / \mathrm{m}^{2}$. The depth averaged stream-wise velocity profile follows an "S-curve" shape across the channel width. It is obtained that the curve is steeper for higher vegetation intensity $\left(N_{2}=1149 \mathrm{IP} / \mathrm{m}^{2}\right)$. At non-vegetated part, velocity increases for vegetated cases comparing to $\mathrm{NV}$ case $\left(N_{0}=0 \mathrm{IP} / \mathrm{m}^{2}\right)$. Increasing of the velocity is higher for higher vegetation intensity case due to its higher obstruction in the vegetated part. This higher obstruction results in higher velocity difference between vegetated and non-vegetated parts.

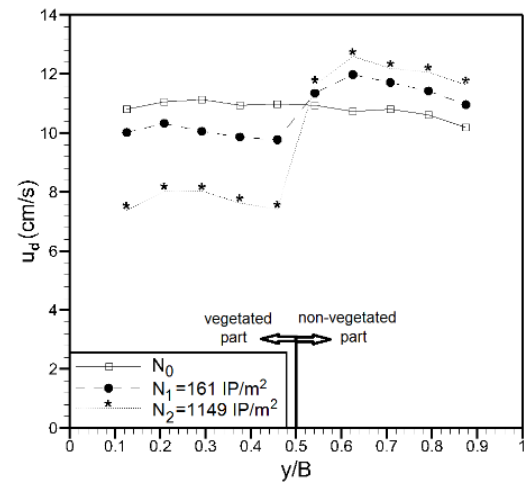

Figure 6: Depth-averaged streamwise velocity distribution along the measurement cross section for all cases.

The turbulent kinetic energy (Figure 7) was calculated with the following equation

$$
k=\frac{1}{2}\left(\overline{u^{\prime 2}}+\overline{v^{\prime 2}}+\overline{w^{\prime 2}}\right)
$$

Where $u^{\prime}, v^{\prime}$, and $w^{\prime}$ are the fluctuating velocity values in $x, y$, and $z$ directions respectively. It is obtained that turbulent kinetic energy peaks at the vegetation interface for higher vegetation intensity $\left(N_{2}=1149 \mathrm{IP} / \mathrm{m}^{2}\right)$ where the resistance is bigger with respect to the lower vegetation intensity $\left(N_{1}=161 \mathrm{IP} / \mathrm{m}^{2}\right)$ in vegetated part.
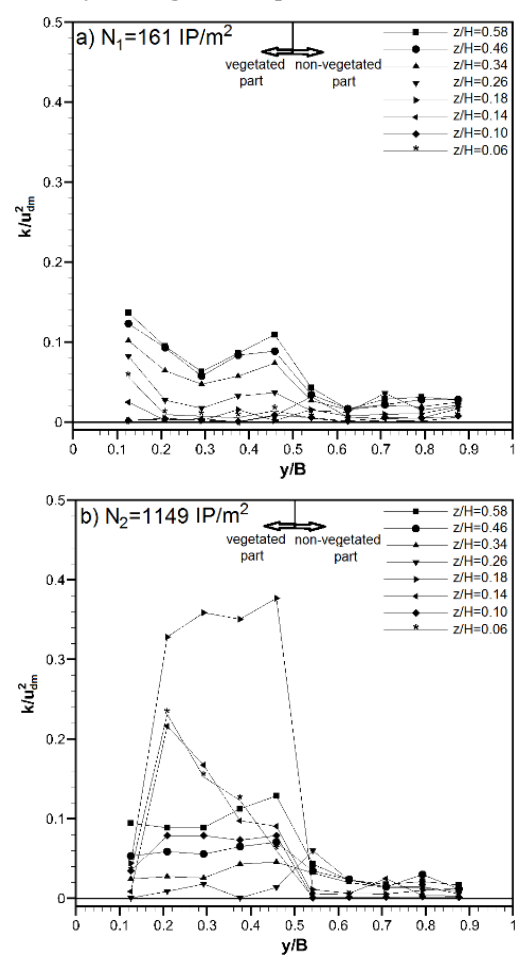

Figure 7: Turbulent kinetic energy profiles across the channel width for, a): $N_{1}=161 \mathrm{IP} / \mathrm{m}^{2}, \mathrm{~b}$ ): $N_{2}=1149 \mathrm{IP} / \mathrm{m}^{2}$. 
Turbulent kinetic energy reduces with decreasing vegetation intensity in the vegetated part. Apart from this, turbulent kinetic energy is always lowest in the non-vegetated part comparing to the vegetated part.

The lateral momentum exchange (Figure 8) was evaluated using Reynolds Stress $<-\overline{u^{\prime} v^{\prime}}>$. Reynolds Stress distribution shows that higher vegetation intensity causes strong increase in the lateral momentum especially at the interface between the inner layer and outer layer at the vegetated part. In the non-vegetated part lateral momentum is close to zero for both vegetation intensities cases.
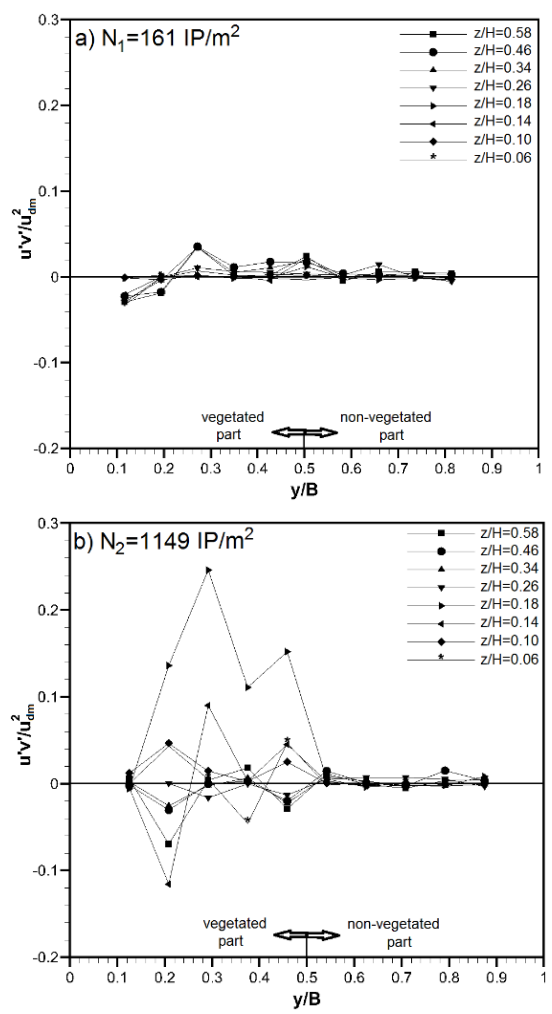

Figure 8: Reynolds Stress $\left(u^{\prime} v^{\prime}\right)$ profiles across the channel width for, a): $N_{1}=161 \mathrm{IP} / \mathrm{m}^{2}$, b): $N_{2}=1149 \mathrm{IP} / \mathrm{m}^{2}$.

The vertical momentum exchange (Figure 9) was also evaluated using Reynolds Stress $\left\langle-\overline{u^{\prime} w^{\prime}}\right\rangle$. Reynolds Stress distribution shows that higher vegetation intensity causes strong increase in the vertical momentum especially at the interface between the inner layer and outer layer at the vegetated part similar to lateral momentum exchange. The lateral momentum has bigger magnitude than vertical momentum exchange in the vegetated part. In the nonvegetated part vertical momentum is close to zero for both vegetation intensity cases.

The effect of vegetation density on the channel capacity was also obtained by calculating discharge (Figure 10). For this purpose, the cross-section divided into four parts and discharges at these parts were calculated using mean depth averaged velocities of every part. The discharge values were decreased in vegetated part when increased at the nonvegetated part. The percentages of the discharge reduction over the cross-section were calculated as $3 \%$ and $12 \%$ for vegetation intensities $N_{1}=161 \mathrm{IP} / \mathrm{m}^{2}$ and $N_{2}=1149 \mathrm{IP} / \mathrm{m}^{2}$ respectively. From this point it can be concluded that discharge capacity of the channel decreases with increasing vegetation intensity.
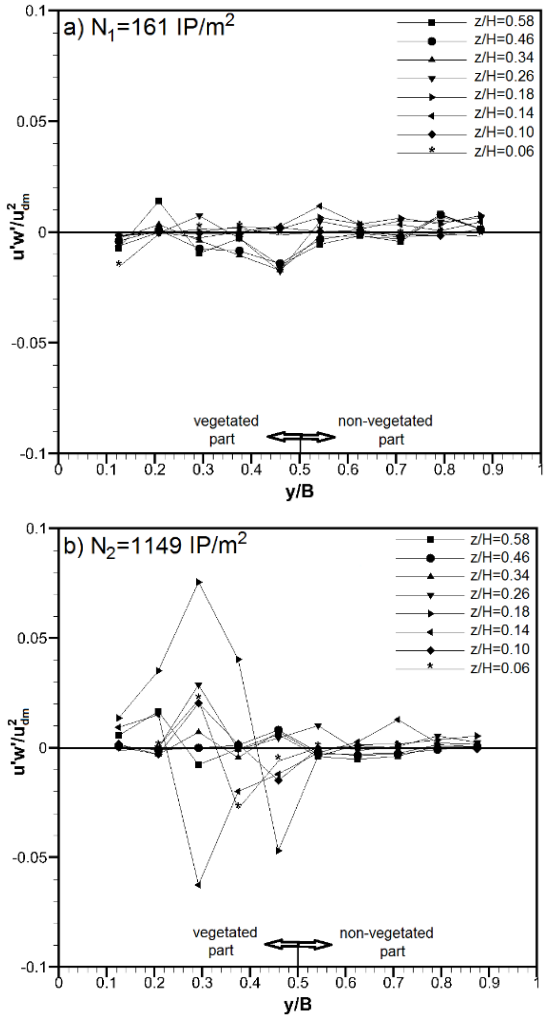

Figure 9: Reynolds Stress $\left(u^{\prime} w^{\prime}\right)$ profiles across the channel width for a): $N_{1}=161 \mathrm{IP} / \mathrm{m}^{2}$, b): $N_{2}=1149 \mathrm{IP} / \mathrm{m}^{2}$.

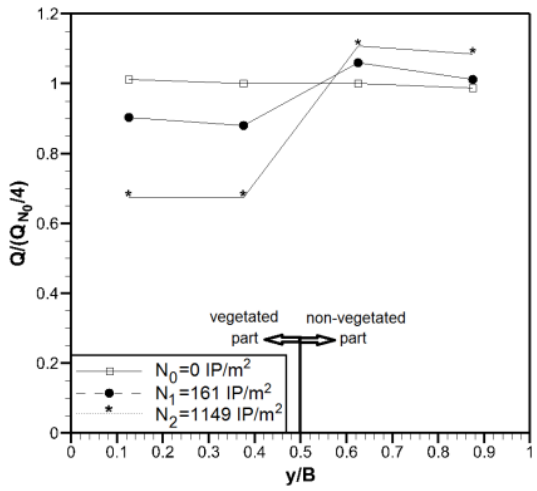

Figure 10: Discharge values for different vegetation densities at different parts of the cross-section of the channel.

\section{Conclusions}

The submerged vegetation generally occurs in shallow regions and aquatic flow occurs over this permeable porous area. In this type of flows, the resistance applied by vegetation, the mixing mechanism caused by vortices behind and over the vegetation and vertical transport across the vegetation-water interface become important phenomenons in the flow. As a result, the fully developed flow condition may not be representative of the aquatic flow. Therefore, the aquatic flows should be examined considering different type of submerged vegetation and flow conditions. In this study, the flow structure caused by a finite-length submerged vegetation patch in an open-channel cross-section was investigated for different vegetation densities experimentally.

In general, analysis of the experimental results concluded that the presence of vegetation causes strong gradient in the flow 
structure over the cross-section of the channel. The relative influence of vegetation was greater under higher vegetation intensity where vegetation has greater blockage effect in the flow.

Vegetation layer causes decrease in the streamwise velocity at vegetated part especially in the inner layer (vegetation layer) where it causes increase in the non-vegetated part. The higher vegetation intensity causes higher velocity difference in the velocity distribution. The "S-curve" shaped depth averaged stream-wise velocity profile was obtained across the channel width with steeper curve for higher vegetation intensity.

Turbulent kinetic energy and momentum exchanges in lateral and vertical directions were also evaluated to understand the effect of vegetation on the turbulent structure. Turbulent kinetic energy is higher in the vegetated part comparing to non-vegetated part. Additionally, turbulent kinetic energy peak occurs at the vegetation interface between inner and outer layer in the vegetated part for higher vegetation intensity. According to the lateral and vertical momentum exchange results, it is obtained that strong momentum exchange appears at the interface between the inner layer and outer layer at the vegetated part for higher vegetation intensity. The lower vegetation intensity doesn't seem to be effective too much on the momentum exchange over the crosssection of the channel. Moreover, it is obtained that discharge capacity of the channel decreases with increasing vegetation intensity.

\section{Acknowledgement}

The author would like to acknowledge the funding of the research project (MF14010) from Adnan Menderes University which allows establishing the experiment flume in the laboratory. The author also thank to Assist. Prof. Dr. Didem YILMAZER from Namık Kemal University who provides ADV for the experiments.

\section{References}

[1] Stoesser T, Salvador G P, Rodi W, Diples P. "Large eddy simulation of turbulent flow through submerged vegetation". Transport in Porous Media, 78(3), 347-365, 2009.

[2] Nezu I, Sanjou M. "Turbulence structure and coherent motion in vegetated canopy open-channel flows". Journal of Hydro-environment Research, 2(2), 62-90, 2008.

[3] Klopstra D, Barneveld HJ, van Noortwijk JM, van Velzen E.H. "Analytical model for hydraulic roughness of submerged vegetation". The 27th Congress of the International Association for Hydraulic Research; Proceedings of Theme A, Managing water: Coping with Scarcity and Abundance. New York, USA, 10-15 August 1997.
[4] Wilson CAME. "Flow resistance models for flexible submerged vegetation". Journal of Hydrology, 342(3-4), 213-222, 2007.

[5] Righetti M. "Flow analysis in a channel with flexible vegetation using double averaging method". Acta Geophysica, 56(3), 801-23, 2008.

[6] Huthoff F, Augustijn DCM, Hulscher SJMH. "Analytical solution of the depth averaged flow velocity in case of submerged rigid cylindrical vegetation". Water Resources Research, 43(6), 129-148, 2007.

[7] Murphy E, Ghisalberti M, Nepf H. "Model and laboratory study of dispersion in flows with submerged vegetation". Water Resources. Research, 43(5), 1-12, 2007.

[8] Huai WX, Zeng YH, Xu ZG, Yang ZH. "Three-layer model for vertical velocity distribution in open channel flow with submerged rigid vegetation". Advances in Water Resources, 32(4), 487-492, 2009.

[9] Cheng NS. "Representative roughness height of submerged vegetation”. Water Resources Research, 47(8), $1-6,2011$.

[10] Chen SC, Kuo YM, Li YH. "Flow characteristics within different configurations of submerged flexible vegetation". Journal of Hydrology, 398(1-2), 124-134, 2011.

[11] Nepf HM, Ghisalberti M. "Flow and transport in channels with submerged vegetation". Acta Geophysica, 56(3), 753-777, 2007.

[12] Nepf HM, Vivoni ER. "Flow structure in depth-limited, vegetated flow". Journal of Geophysical Research, 105(12), 28547-28557, 2000.

[13] Nezu I, Onitsuka K. "Turbulent structures in partly vegetated open-channel flows with LDA and PIV measurements". Journal of Hydraulic Research, 39(6), 629-642, 2001.

[14] Zong L, Nepf H. "Flow and deposition in and around a finite patch of vegetation". Geomorphology, 116(3-4), 363-372, 2010.

[15] Zong L, Nepf H. "Spatial distribution of deposition within a patch of vegetation". Water Resources Research, 47(3), 1-9, 2011.

[16] Nehal L, Yan ZM. "Study on the flow of water through non-submerged vegetation". Hydrology Days, 1, 170-179, 2005.

[17] Li S, Shi H, Xionga Z, Huai W, Cheng N. "New formulation for the effective relative roughness height of open channel flows with submerged vegetation". Advances in Water Resources, 86, 46-57, 2015.

[18] Okamoto T, Fujimoto Y, Toda K, Nezu I. "Development of coherent structure and turbulence behind a finite-length emergent vegetation patch in open-channel flow". River Flow 2014, International Conference on Fluvial Hydraulics, Lausanne, Switzerland, 3-8 September 2014. 